УДК 352.07(477-21/-22)

DOI: 10.34132/pard2019.04.04

\title{
ОРГАНИ САМООРГАНІЗАЦІЇ НАСЕЛЕННЯ В УКРАЇНІ: СУЧАСНИЙ СТАН, ПРОБЛЕМИ ТА ПЕРСПЕКТИВИ РОЗВИТКУ
}

Свтушенко О.Н., д-р політ. наук, професор, Чорноморський національний університет імені Петра Могили, м. Миколаїв, Україна

Стадніченко Л.М., магістр управління та адміністрування, Державна служба з лікарських засобів та контролю за наркотиками у Миколаївській області, м. Миколаїв, Україна

У статті досліджується сучасний стан, проблеми та перспективи розвитку органів самоорганізації населення в містах України, зокрема в місті Миколаєві, їх ролі в системі місцевого самоврядування в умовах децентралізачії державної влади. Виокремлено як позитивні, так і негативні аспекти їх діяльності.

До позитивних треба віднести те, щуо органи самоорганізащії населення там де вони дійсно працюють є достатньо ефективним інструментом вирішення населенням громади питань місиевого значення, тому щзо наближені до жителів певної території (вулиці, кварталу, мікрорайону). Органи самоорганізації населення активізують населення навколо невирішених місцевих проблем, сприяють розвитку демократії на місцевому рівні, тому щзо справжня демократія й починається з особистої участі населення у вирішенні питань, які стосуються їхнього життя.

До негативних тендениій розвитку органів самоорганізації населення треба віднести: складну прочедуру їх створення; відсутність налагодженої системи взаємодї між територіальною громадою й органами місцевого самоврядування; незацікавленість органів місиевого самоврядування в органах самоорганізації населення, а тому небажання враховувати пропозицї громадян й залучати їх до розв 'язання місиевих проблем; недостатня фінансова 
підтримка, заохочення та стимулювання органів самоорганізащії населення з боку органів місиевого самоврядування; патерналістські очікування населення, сподівання, щуо влада повинна вирішувати всі їх проблеми; низка активність громадян, як реальної впливової сили у вирішенні проблем території громади, люди не вірять, щэо зможуть щзось реально змінити в місті, селі, селищі.

Визначено, що саме органи самоорганізачії населення в умовах децентралізації й реформування місцевого самоврядування можуть стати допоміжним ресурсом місцевої владі у вирішенні проблем соціального, економічного та культурного життя громадян на рівні територіальної громади, сприяти їх самоорганізації, розвитку ініиіативи й відповідальності. Проте розуміння того факту, щцо органи самоорганізації населення - ие ефективний інструмент реалізації місиевих питань та розвитку краӥни, як демократичної держави, спонукає лиш невелику кількість територіальних громад активно розвивати та підтримувати діяльність органів самоорганізації населення.

Ключові слова: органи самоорганізачії населення, місиеве самоврядування, органи місиевого самоврядування, державна влада, демократія, децентралізація, територіальна громада.

\section{Постановка проблеми у загальному вигляді.}

В умовах децентралізації державної влади й реформи місцевого самоврядування (далі МСВ), зокрема у розвитку житлово-комунальної сфери, усе більшої актуальності набуває питання пов'язано 3 діяльністю органів самоорганізації населення (далі $\mathrm{OCH}$ ), які повинні сприяти органам МСВ вирішувати різноманітні питання, насамперед з розвитку території громади. Саме ОСН є одним 3 найбільш ефективних інструментів вирішення територіальною громадою питань 3 благоустрою території: будинків, вулиць, мікрорайонів тощо, оскільки вони $є$ найбільш наближеними до населення представницькими органами.

Ефективність ОСН породжується першоджерелом їх створення: як показує практика, якщо ініціатива йде безпосередньо від жителів певної території (вулиці, кварталу, мікрорайону), які, як правило, згуртовуються навколо якоїсь проблеми, і буде підтримана 
органом МСB, такі ОСН є більш ефективними, ніж ті, створення яких нав'язано владою. Тому що ОСН - це не тільки форма самоорганізації населення, це інструмент за допомогою якого населення самостійно й під власну відповідальність вирішує питання благоустрою території на якої воно проживає.

Однак, треба підкреслити, що потенціал ОСН, як ефективного інструменту реалізації місцевих питань та розвитку країни, як демократичної держави, досі в Україні не використовується повною мірою.

Аналіз останніх досліджень та публікацій. Сучасний науковий доробок у вивченні питань пов'язаних з організацією ОСН, як законодавчо закріплену форму об'єднань громадян, що є складовою частиною інституту місцевого самоврядування, представлений численними працями українських дослідників, таких як: В. Андріяш, М. Баймуратов, О. Батанов, В. Борденюк, О. Бориславська, Я. Глазова, В. Григор'єв, О. Свтушенко, В. Смельянов, Я. Жовнірчик, А.Ібрагімова, В. Кампо, М. Корнієнко, А.Кравченко, О. Литвин, Т. Лушагіна, Н. Максишко, А. Мукшименко, М. Мягченко, О. Орловський, В. Прошко, С. Рудик, С. Саханенко, І. Яковець а ін. Проте більшість праць присвячені загальним проблемам організації й діяльності ОСН і невелика кількість досліджень стосується стану розвитку ОСН в містах України, особливо в умовах децентралізації.

Формулювання цілей статті (постановка завдання). Метою статті - є здійснення аналізу сучасного стану проблем та перспектив розвитку ОСН в містах України, зокрема в місті Миколаєві, їх ролі в системі МСB, особливості їх взаємодії з органами МСВ територіальних громад в умовах децентралізації державної влади та на підставі позитивних аспектів їх діяльності запропонувати шляхи покращення діяльності ОСН.

\section{Викладення основного матеріалу дослідження.}

Демократичний рівень розвитку нашої країни в першу чергу залежить від реальної участи громадян, зокрема на рівні територіальних громад (далі ТГ) вирішувати питання місцевого значення. Вирішення питань місцевого значення тісно пов'язане з розвитком МСВ, однією зі складових якої є ОСН, які з точки зору конституційних прав людини й громадянина є механізмом реалізації їх конституцій- 
них прав брати участь у вирішенні власних першочергових нагальних потреб. ОСН створюються згідно ст. 140 Основного Закону [9], ст. 1 Закону «Про місцеве самоврядування в Україні» [18] сільськими, селищними, міськими радами за ініціативою жителів будинків, вулиць, кварталів на строк повноважень місцевої ради, яка наділяє їх частиною власної компетенції, фінансів, майна. ОСН згідно закону Про ОСН ст. 3 п.3 повинні задовольняти соціальні, культурні, побутові та інші потреби населення, сприяти органам МСВ у наданні ними відповідних послуг, здійснювати громадський контроль за діяльністю органів МСВ та інших постачальників послуг [19].

Стан розвитку ОСН в місті Миколаєві загалом відображає загальноукраїнську картину розвитку цих органів: сплеск їх формування припадає на 2003-2007 роки та 2012-2013 роки з подальшим незначним розвитком і змінився на спад у 2014 роки [1]. За реформи децентралізації та територіальної організації влади, що де-юре розпочалась 32014 року та реально стартувала з 2015 року з утворенням об'єднаних територіальних громад (далі ОТГ), органи МСВ отримали достатні повноваження, необхідні фінансові ресурси та можливості самостійно ухвалювати рішення та нести відповідальність за їх реалізацію [8].

Однак в умовах обмеженості людських та часових ресурсів для виконання покладених на органи МСВ повноважень, саме ОСН можуть стати допоміжним ресурсом МСВ у вирішенні проблем соціального, економічного та культурного життя громадян на рівні ТГ, сприяти їх самоорганізації, розвитку ініціативи й відповідальності. Проте розуміння цього факту спонукає лиш невелику кількість ТГ України активно розвивати та підтримувати діяльність ОСН.

На сьогодні стан розвитку ОСН м. Миколаєва характеризується досить негативною тенденцією. Так, за офіційною інформацією виконавчого комітету Миколаївської міської ради за період 2015-2018 pp. на території м. Миколаєва створено лише 1 ОСН (2015 рік). Загальна кількість ОСН, легалізованих виконкомом Миколаївської міської ради станом на 01.11.2018 - 33 .

Динаміка розвитку ОСН, які легалізовані Миколаївською міською радою подана на рис. 1. 


\section{Кількість ОСН по рокам}

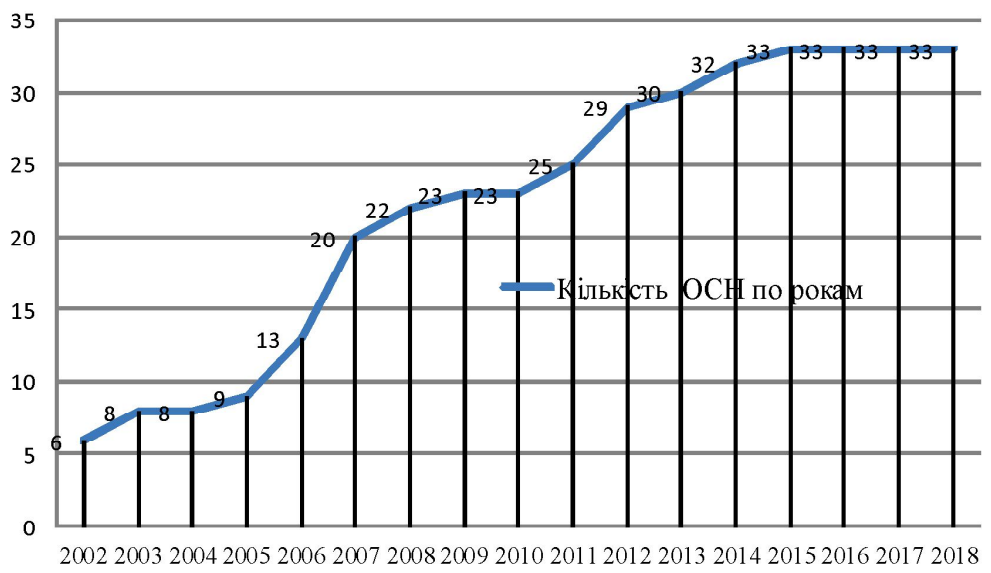

Рис. 1. Динаміка розвитку легалізованих ОСН в м. Миколаєві

Цікавим видається й аналіз стосовно розвитку окремих видів ОСН в м. Миколаєві. Так, станом на березень 2018 р. легалізовані такі види ОСН: 22 будинкові комітети, 2 вуличних, 2 квартальних та 7 ОСН мікрорайонів (рис. 2).

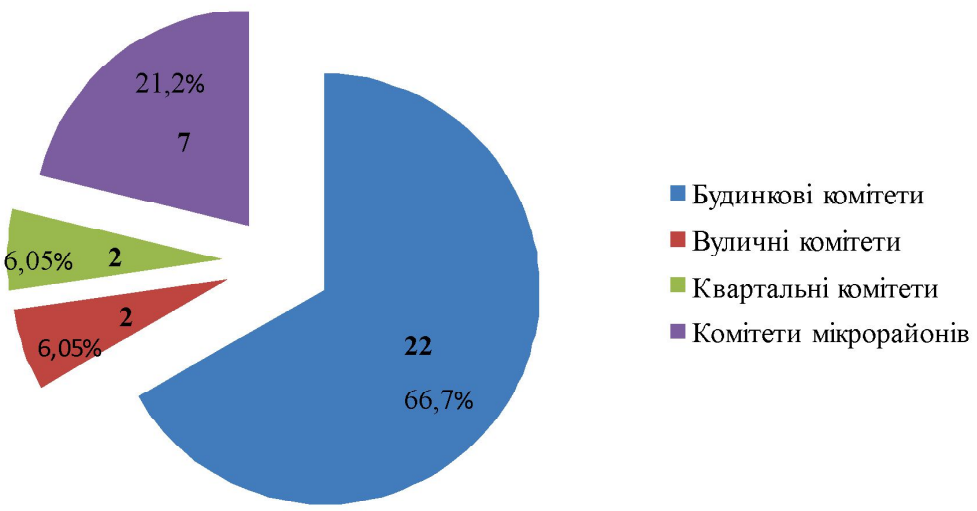

Рис. 2. Кількість легалізованих ОСН м. Миколаєва за видами 
Тим часом серед 47 ОСН м. Одеси - 44 (93,6 \%) - це комітети мікрорайонів, а 3 (6,4 \%) - квартальні комітети [7]. Очевидно, що такий вид ОСН як комітети мікрорайонів $є$ більш ефективним і життєздатним, враховуючи масштаби, які може охопити своєю участю, у порівнянні з будинковим комітетом, а також враховуючи можливе переорієнтування будинкових комітетів на створення об'єднань співвласників багатоповерхових будинків (далі ОСББ), які, як юридичні особи мають більше повноважень, більший вплив для вирішення питань життєдіяльності будинку, участь у державних та місцевих програмах, де однією з умов участі є реєстрація юридичної особи (наприклад, програма «Теплі кредити», міська програма модернізації ліфтів та ін.).

На підтвердження цьому є аналіз даних щодо легалізованих $\mathrm{OCH}$, що наявні на офіційному сайті Миколаївської міської ради. Слід зазначити, що серед $33 \mathrm{OCH}$ у $22 \mathrm{OCH}$ (серед яких 13 - саме будинкові комітети) термін повноважень органу не подовжений, тобто фактично в місті функціонує всього $11 \mathrm{OCH.} \mathrm{Натомість} \mathrm{кіль-}$ кість ОСББ в м. Миколаєві за останні роки стрімко зростає. Так, за офіційним повідомленням департаменту ЖКГ Миколаївської міської ради з 583 ОСББ більш ніж половина (297) було створено протягом 2015-2018 років. Створення ОСББ дозволяє власникам квартир самостійно вирішувати питання управління багатоквартирним будинком. I хоча ототожнювати поняття ОСББ та ОСН не можна: вони є різними за нормативно-правовою основою діяльності, походженням, призначенням, але, на наш погляд, вже створеним $\mathrm{OCH}$, як органу з більш широкою компетенцією щодо мешканців певної міської території, слід активно співпрацювати з ОСББ, які представляють інтереси організованих у них мешканців багатоквартирних будинків. Поєднання зусиль цих двох форм місцевої ініціативи в питаннях благоустрою територій, контролю за якістю послуг в житлово-комунальній сфері може дати значний результат. Крім того, за умови популяризації ОСН місцевою владою, як форми безпосереднього самоврядування, слід використовувати потенціал активних членів ОСББ та сприяти їх консолідації та утворення ОСН на відповідній території для відстоювання своїх інтересів. I як слушно за- 
уважують науковці, «ОСН доцільно створювати там, де народ вже об`єднався і становить актуалізовану спільноту» [5, с. 49].

На нашу думку, позитивний досвід організації ОСН, утвореного на базі декількох ОСББ на відповідній території, міг би стати для вирішення питань забудов на території відповідної вулиці, мікрорайону тощо, адже прийнятий Закон України «Про регулювання містобудівної діяльності» від 17 лютого 2011 р. [20] фактично звузив можливості громадськості впливати на забудову території громади. По-перше, зі сфери обговорення на громадських слуханнях у новому законі було вилучено таке важливе питання, як містобудівне обгрунтування розміщення об'єктів містобудування. Відповідно до ст. 21 зазначеного закону тепер предметом громадських слухань не може бути будівництво окремих конкретних об'єктів, на громадські слухання виносяться тільки розроблені проекти генерального плану, що призводить до того, що думка громадян, що проживають на відповідній території не враховується при забудові таких територій, що дає змогу розміщувати екологічно шкідливі об'єкти, як то заправки, чи об'єкти комерційного походження, здійснювати несанкціоновані забудови, без врахування думки жителів відповідної території. I хоча місцева влада відповідно до своїх повноважень може локальними нормативними актами встановлювати обов'язковість узгодження з ОСН нових забудов, на практиці ця норма видається фантасмагоричною. В цій ситуації ОСН могли б стати дієвим механізмом в протистоянні з несумлінними забудовниками та спонукати місцеву владу прислухатись до думки відповідної громади, надаючи дозволи на розміщення нових об'єктів будівництва.

Очевидно, що тенденція до спаду активності ОСН пов'язана як 3 уже дослідженими проблемами створення та існування ОСН (це і складна процедура створення, і необхідність подовження повноважень органу у зв'язку із закінченням терміну повноважень ради для подальшої легітимної діяльності ОСН, і проблеми в делегуванні повноважень ОСН відповідними радами), так із низькою зацікавленістю міської ради до залучення громадськості у вирішення питань місцевого значення. Так, за останні 3 роки Миколаївською міською радою не було проведено жодного офіційного заходу, спрямованого 
на створення та розвиток ОСН на території м. Миколаєва. Згідно 3 інформацією, висвітленою на офіційному сайті ради такі заходи востаннє проводились в 2014-2015 роках.

Наприклад, Департаментом суспільних комунікацій виконавчого органу Київської міської ради (Київської МДА) у рамках виконання заходів міської цільової програми «Сприяння розвитку громадянського суспільства у м. Києві на 2017-2019 роки» спільно з Центром перепідготовки та підвищення кваліфікації працівників органів державної влади, органів місцевого самоврядування, керівників державних підприємств, установ та організацій тільки за 2017 рік було проведено дев ять заходів, спрямованих на підвищення кваліфікації керівниками та членами ОСН (семінари, круглі столи, тренінги) з актуальних питань організації роботи ОСН та взаємодії ïx 3 органами МСВ. В травні 2017 р. в м. Києві проведено перший форум організацій громадянського суспільства міста, де спілкувалися представники столичної влади, громадськості, ОСН та міжнародних фондів.

Заслуговує на довіру приклад створення та діяльності на базі ОСН м. Києва громадських інспекторів з благоустрою, які активно допомагають владі Києва у боротьбі з незаконно встановленими МАФами, що є також проблемою м. Миколаєва. По декілька членів ОСН майже з усіх мікрорайонів Києва отримали посвідчення громадських інспекторів 3 благоустрою та проводять свою діяльність відповідно до ст. 41 Закону України «Про благоустрій населених пунктів» [14], а також розпорядження КМДА «Про громадський контроль у сфері благоустрою м. Києва» [15].

Однією із головних форм роботи є проведення рейдів 3 перевірки стану благоустрою мікрорайонів, за результатами яких, у разі виявлення незаконних забудівель, встановлення нових МАФів, появу стихійної торгівлі громадські інспектори мають право перевіряти документи, та у разі їх відсутності складати протоколи та акти 3 пропозиціями до РДА. У полі зору громадських інспекторів з благоустрою $є$ також освітлення вулиць, стан пішохідних тротуарів, стан зеленої зони та наявність сухостою на території мікрорайонів, контроль за прибиранням прибудинкових територій, вивезенням 
твердих побутових відходів, негабаритного сміття, а також опалого листя та очищенням території від снігу. Діяльність громадських інспекторів дає можливість виявляти проблеми, які потребують вирішення на окремих територіях, які в подальшому стають предметом діяльності відповідного ОСН.

Наразі в Україні існують й інші приклади громад, які приділяють багато уваги розвитку цієї форми місцевої муніципальної демократії, яка допомагає державі подолати недовіру населення до влади та $є$ однією з найважливіших умов побудови громадянського суспільства.

Гадаємо, слід звернутись до досвіду громади м. Одеси, де одними із перших в Україні виникли ОСН. Про важливість місця, яке посідають ОСН у житті ТГ, свідчить той факт, що у структурі міської ради створений відповідний підрозділ - Управління 3 питань взаємодії з ОСН. В Одесі багаторічний досвід застосування механізму соціального замовлення постійно підвищує рівень компетентності ОСН як виконавця соціальних послуг та розширює коло таких послуг. ОСН отримують перемогу в конкурсах за напрямами: сприяння зайнятості та довголіттю людей похилого віку; соціально-психологічна реабілітація та адаптація внутрішньо переміщених осіб, учасників АТО та членів їх родин; вирішення соціальних проблем молоді; захист навколишнього середовища; профілактика ВІЛ/СНIДУ та наркоманії, популяризації здорового способу життя. 32012 року успішно реалізується пілотний проект по створенню в ОСН постійно діючих бригад з благоустрою територій мікрорайонів, які не обслуговуються житлово-експлуатаційними організаціями [7].

В 2015 році Одеською міською радою затверджено міську цільову Програму розвитку ОСН в м. Одесі на 2016-2019 роки, бюджетом міста виділено 22412, 1 тис. грн. для забезпечення реалізації програми, в 2018 році бюджет було збільшено до 26870, 9 тис. грн. Результатом прийняття та реалізації програми згідно звіту про виконання Програми за 2017 рік [22] стало збільшення кількості ОСН 338 (на 01.11.2015 р.) до 47 (на кінець 2017 р.).

Реалізовані заходи Програми забезпечили можливість ширшого охоплення території міста діяльністю ОСН, що дозволило значною 
мірою підвищити участь населення у вирішенні питань місцевого значення, реалізації соціально-економічного, культурного розвитку відповідних територій міста. У результаті виконання заходів Програми поліпшилась організаційна і фінансова спроможність реалізації власних та делегованих повноважень ОСН міста Одеси шляхом надання їм фінансової підтримки, сприяння безпосередній участі громадян у вирішенні проблем територіальної громади міста, залучення ОСН м. Одеси до виконання суспільно значущих для міста завдань. Програмою фінансувались технічні та організаційні засоби для інформування мешканців на території діяльності ОСН про їх роботу (друковані або тиражовані інформаційні матеріали, бюлетені, оголошення тощо), що сприяє більшій обізнаності жителів громади про наявність такої форми МСВ, формує у свідомості громадян позитивізм їх участі у вирішенні актуальних проблем життєдіяльності міської громади. Завдяки реалізації Програми у 2017 році покращено добробут та якість життя мешканців міста Одеси, створено належні умови для участі жителів у вирішенні окремих питань місцевого значення, здійснення конкретних заходів, спрямованих на затвердження в місті атмосфери взаємної довіри та конструктивної співпраці між ОМС і міською ТГ.

В м. Миколаєві така програма була затверджена в 2011 році [16]. Одним із заходів Програми в м. Миколаєві на 2012-2013 роки стала розробка процедури здійснення ОСН контролю якості надання житлово-комунальних послуг. Програма передбачала проведення моніторингу стану розвитку ОСН та досліджень проблем їх діяльності з боку органів МСB, а також проведення моніторингу діяльності ОСН громадськими організаціями.

Вагома частина бюджетних ресурсів, виділених на виконання Програми м. Миколаєва, спрямовувалась на проведення щорічних конкурсів проектів ОСН «Шанс для реалізації ідей» (130 тис. грн.), що, на наш погляд, дало можливість реалізувати починання, спрямовані на благо жителів і розвиток міських територій для членів Миколаївських будинкових, вуличних, квартальних комітетів.

Також в межах програми були виділені кошти на здійснення заходів інформаційної кампанії серед мешканців міста щодо переваг 
створення ОСН (91 тис. грн.); проведення семінарів, консультацій та різних навчальних курсів представників $\mathrm{OCH} з$ різних аспектів їх діяльності, у тому числі з питань залучення коштів донорських та комерційних організацій на проведення діяльності ОСН (46 тис. грн.); випуск методичних матеріалів для ОСН (37 тис. грн.); фінансове забезпечення вивчення досвіду інших міст за участю представників ОСН (25 тис. грн.); розвиток матеріальної бази Ресурсного центру підтримки діяльності ОСН м. Миколаєва - (6 тис. грн.).

Оскільки організація контролю за виконанням Програми не містила вимоги до оприлюднення підсумків виконання заходів програми, звіт за результатами реалізації не був оприлюднений, але вже саме існування такої Програми мало позитивний сигнал для громадськості щодо зацікавленості місцевої влади в залученні інституцій громадянського суспільства, в саме ОСН до вирішення проблем місцевого значення. Але це був тільки сигнал й одинока спроба місцевої влади розвинути такий інститут належного представництва інтересів мікрогромад міста в органах МСB, оскільки надалі програма розвитку ОСН прийнята не була.

В подальшому, з метою створення сприятливих умов для розвитку громадянського суспільства у м. Миколаєві, запровадження ефективного механізму співпраці ОМС та інститутів громадянського суспільства, забезпечення врахування інтересів громадян при виробленні та прийнятті управлінських рішень було затверджено Програму сприяння розвитку громадянського суспільства у м. Миколаєві на 2014-2015 роки (далі - Програма) [17].

Метою Програми було створення та подальший розвиток сприятливих умов для задоволення інтересів, захисту прав і свобод людини та громадянина, становлення громадянського суспільства на засадах впровадження принципів належного врядування, сприяння громадській активності, залученню громадян та інститутів громадянського суспільстві до формування і реалізації місцевої політики та збереженню громадянського порозуміння в м. Миколаєві. Проте, на нашу думку, в даній програмі такий різновид інститутів громадянського суспільства, як ОСН просто «розчинився». Заходів, що сприяли б саме розвитку такого інституту, Програмою було передбачено вкрай мало, 
передбачено лише організація та проведення конкурсу проектів ОСН м. Миколаєва «Шанс для реалізації ідей» та фінансування переможців проекту. Після 2015 року розвиток ОСН не був прямо закріплений в програмних документах місцевої влади, наслідком цього вважаємо повну відсутність розвитку ОСН після 2015 року.

Погоджуємось 3 думкою аналітиків Національного інституту стратегічних досліджень, що найбільш успішних результатів у розв'язанні місцевих проблем досягають ОСН у тих ТГ, де органи МСВ ухвалюють статути, локальні програми сприяння розвитку $\mathrm{OCH}$, залучають ці представницькі інституції до виконання цільових програм, впроваджують механізми соціального замовлення та співфінансування у реалізації проектів з розвитку територій громад [13].

Слід також взяти за взірець ефективну практику самоорганізації населення, яка діє у Вінниці. 32007 р. у місті створено асоціацію OCH, яка об'єднує 24 комітети. За підтримки місцевої влади ця Асоціація стала головною дійовою особою у вирішенні питань благоустрою, прокладання каналізації, асфальтування доріг, ремонту та очищення криниць загального користування на умовах співфінансування мешканців та місцевого бюджету. Лише у 2017 р. за таких умов проведено асфальтування дорожнього покриття на 35 вулицях, збудовано 8,5 км мереж водопроводу та каналізації в мікрорайонах приватного сектору забудови міста [6].

Наявність реального потенціалу розвитку даного інституту громадянського суспільства, важливість ОСН для сталого розвитку міста, як форми здійснення МСВ, спонукало до затвердження чергової Програми розвитку ОСН в м. Вінниці на 2017-2021 роки, розробником якої виступила Асоціація ОСН. На нашу думку, зусилля місцевої ради та її співпраця з активними суб'єктами місцевої політики, зокрема ОСН, ОСББ, зацікавленість місцевої влади в розвинутих інститутах громадянського суспільства $є$ одним 3 важелів, що дозволила Вінниці в щорічному рейтингу комфортності міст України, який склав журнал «Фокус», стати другим містом в Україні по комфортності життя [4]. Натомість Миколаїв опинився на 21, передостанньому місті, примітно, що якість муніципальних послуг та міської інфраструктури було оцінено в 2,2 бала за п'ятибальною 
шкалою, 0 балів одержав Миколаїв за показником задоволеності жителів роботою міського голови.

Популяризації створення та діяльності ОСН сприяють постійні висвітлення діяльності ОСН в друкованих засобах масової інформації, в тому числі й спеціалізованих, що дасть змогу членам та керівникам ОСН як більш ефективно орієнтуватись в мінливому законодавстві України, так і застосовувати досвід вирішення територіальних проблем іншими ОСН для своїх потреб. Прикладом тут може стати м. Київ, яке має своє постійне інформаційно-довідкове видання «Вісник ОСН», яке виходить 1 раз на квартал та є фактично практичним посібником для діяльності ОСН, робочим інструментом для тих, хто отримав довіру від людей, що живуть поряд, забезпечувати їхнє комфортне життя, робити побут безпроблемним, контролювати якість послуг, без яких людина нині не обходиться. Засновником даного видання $є$ Головне управління з питань внутрішньої політики та зв'язків з громадськістю Київської МДА, що свідчить про підтримку органами МСВ такої форми локальної демократії, як ОСН.

Крім того, на наш погляд, досить позитивним є досвід організації інформаційного простору для ОСН та мешканців ТГ столиці, шляхом наявності всієї інформації щодо створення та функціонування ОСН на офіційному сайті Київської міської ради. Так, на сайті у розділі «Громадська участь» передбачено підрозділ «Самоорганізація населення», де детально висвітлені нормативні підвалини створення $\mathrm{OCH}$, оперативно висвітлюються результати розгляду заяв про ініціювання створення ОСН, що усуває необхідність зайвий раз відвідувати владні кабінети. Крім того, на цьому ресурсі розміщено перелік ОСН міста з гарною пошуковою системою. В картках конкретного ОСН висвітлено необхідна контактна інформація, дні та години прийому громадян, розміщуються плани та звіти 3 діяльності ОСН, наявна інформація про фінансування за рахунок коштів місцевого бюджету, висвітлюються повідомлення про дату й місце проведення звітних конференцій ОСН та інша необхідна інформація. Все це дає можливість зацікавленим громадянам отримати необхідну інформацію щодо ОСН, а місцева влада позиціонується партером громадянського суспільства. 
Таким чином, позитивний досвід розвитку ОСН в українських містах навіть в умовах законодавчої недосконалості дає можливість місцевій владі, зокрема Миколаївщини, вивчаючи та впроваджуючи дані механізми, формувати дієві групи допомоги для ефективного виконання своїх повноважень в частині вирішення проблем міста, яке складається саме 3 таких невеликих осередків як будинок, вулиця, квартал. У цій ситуації ОСН можуть стати важливим елементом системи управління громадою міста та доповнити систему представництва інтересів малих громад.

Звичайно, розвиток ОСН не залежить тільки від зусиль місцевої влади. Важливим критерієм для розвитку $\mathrm{OCH} є$ формування громадянських компетентностей українців. На нашу думку, освіта, громадянська освіта, виховання активних і відповідальних громадян повинні стати ключовими в переліку першочергових внутрішньополітичних завдань української держави. Розуміючи важливість розвитку цього критерію в Стратегії сприяння розвитку громадянського суспільства в Україні на 2016-2020 роки, що прийнята відповідно до Указу Президента «Про сприяння розвитку громадянського суспільства в Україні» [21] у рамках стратегічного напряму визначено: створення сприятливих умов розвитку організацій громадянського суспільства; активізація заходів, спрямованих на підвищення громадянської освіти населення щодо можливості захисту своїх прав та інтересів через різні форми демократії участі.

Якщо конкретніше розкривати громадянські компетентності, їх ціннісні складники, то вони мають в собі здатність, спроможність людини діяти активно, відповідально, реалізуючи власні громадянські права й обов'язки. А це створює передумови для формування вищого рівня громадянської культури, злагоди, консенсусу, толерантності між людьми. Потрібно зазначити, що завдяки компетентностям людина спроможна не тільки оцінювати те, що відбувається в суспільному житті громади, але й робити посильний внесок в ії зміцнення [21].

Важливу роль у формуванні громадянських компетентностей, цінностей, реалізації інтересів мешканців територіальної громади можуть відігравати громадські слухання, круглі столи, як процеси навчання, які базуються на діалозі, відкритості, вільному спілкуванні, довірі. 
Для ОСН, представників ОСББ це шанс публічно донести до місцевої влади проблеми функціонування ОСН та запропонувати шляхи їх розв'язання, а також аргументувати доцільність розширення повноважень цих органів. Участь у слуханнях та круглих столах сприяє їх вільному спілкуванню з посадовими особами МСВ та депутатами, дає змогу простежити механізми формування солідарної відповідальності, отримати знання про порядок ухвалення рішень у раді та внесення місцевих ініціатив. Підвищення рівня громадянської освіченості приведе до збільшення участі членів територіальної громади міста у вирішенні окремих питань місцевого значення, адже спроможність населення до самоорганізації та активної участі $\epsilon$ принциповою ознакою розвитку громадянського суспільства.

Україна успадкувала від Радянського Союзу таку модель соціальної політики, яка сформувала шкідливі патерналістські очікування і сподівання. I це зрозуміло, оскільки не існувало певних умов і механізмів саморозвитку, самореалізації людини, бракувало здорової конкуренції, досить примітивною була система соціального захисту, самозабезпечення та економічного самозахисту людей завдяки державним турботам. Беручи до уваги, що значну частину населення незалежної України представляє «покоління СРСР», на сьогодні дослідники спостерігають негативні прояви патерналістської моделі такі як соціальну пасивність громадян, сподівання на державу як на вищу інстанцію у вирішенні соціальних проблем [23, с. 345].

Незважаючи на появу нового класу громадських діячів, поступовий розвиток громадянського суспільства, патерналістські установки українців, як і раніше дуже сильні. Про це свідчить аналіз опитувань у рамках проекту «Свропейське соціальне дослідження» (ESS) [3]. Українці виступають за більш активну участь саме держави у питаннях скорочення різниці в доходах громадян, соціальне та медичне забезпечення і т. д. На думку національних експертів, більшість українців не відчувають власну відповідальність за стан справ у своїй ТГ і в Україні в цілому.

Громадяни міста Миколаєва не стали виключенням 3 цієї загальноукраїнської тенденції розуміння своєї ролі й ролі держави в підвищенні свого добробуту. Люди ще не розуміють, що демокра- 
тія - це не неможливість виказати своє невдоволення діями влади, демократія - це особиста участь громадян у розв'язанні конкретних питань, котрі безпосередньо стосуються умов їхнього життя. Недарма одним з основних завдань ОСН є створення умов для участі жителів у вирішенні питань місцевого значення.

Однак, як показало проведене нерепрезентативне опитування, серед 150 жителів міста певна частина громадян не тільки не знає про існування ОСН, не усвідомлює їх потенціалу, але й не готова до участі в облаштуванні власного середовища проживання (Табл. 1).

Таблиця 1

\section{Результати опитування жителів м. Миколаїв}

\begin{tabular}{|l|c|c|c|c|}
\hline \multirow{1}{*}{ Поставлені запитання } & \multicolumn{4}{|c|}{ Надані відповіді, \% } \\
\cline { 2 - 5 } & Так & Ні & $\begin{array}{c}\text { Част- } \\
\text { ково }\end{array}$ & $\begin{array}{l}\text { Склад- } \\
\text { но від- } \\
\text { повісти }\end{array}$ \\
\hline $\begin{array}{l}\text { Чи знаєте Ви що таке ОСН, їх } \\
\text { функції? }\end{array}$ & $12,2 \%$ & $31,8 \%$ & $37,7 \%$ & $18,3 \%$ \\
\hline $\begin{array}{l}\text { Чи маєте Ви приклад діяльності } \\
\text { ОСН? }\end{array}$ & $15,3 \%$ & $40,2 \%$ & $29,6 \%$ & $14,9 \%$ \\
\hline $\begin{array}{l}\text { Чи готові Ви ініціювати створен- } \\
\text { ня ОСН в своєму будинку, вулиці, } \\
\text { кварталі тощо? }\end{array}$ & $15,6 \%$ & $40,6 \%$ & $14,8 \%$ & $29 \%$ \\
\hline $\begin{array}{l}\text { Чи вважаєте Ви, що діяльність } \\
\text { такого органу може значно покра- } \\
\text { щити якість життя на території } \\
\text { Вашої мікрогромади? }\end{array}$ & $23,1 \%$ & $43,2 \%$ & $17,8 \%$ & $15,9 \%$ \\
\hline $\begin{array}{l}\text { Чи готові Ви особисто брати } \\
\text { участь в покращенні стану Вашо- } \\
\text { го будинку (двору, вулиці тощо)? }\end{array}$ & $23,5 \%$ & $44,8 \%$ & $21 \%$ & $10,7 \%$ \\
\hline
\end{tabular}

Аналіз опитування показує, що місцеве населення своєю більшістю асоціює ОСН з ОСББ, і хоча ОСББ згідно законодавства прямо не належать до органів самоорганізації, але, враховуючи, що такі 
міні-утворення як ОСББ дають початок реалізації всього того, що відноситься до поняття місцевої (локальної) демократії, їх відповіді були зараховані до категорії часткових знань про ОСН $(37,7$ \%). Як свідчать результати, кількість громадян, які готові брати участь у практичній роботі з покращання території свого проживання, менше тих, хто до цього не готовий. Але привертає увагу великий відсоток тих, хто дав відповідь «Частково» та тих, кому складно відповісти на поставлені запитання. На нашу думку, за відповідної інформаційної роботи та наявності конкретних позитивних прикладів саме ці дві категорії громадян можуть бути резервом активних членів ОСН.

Серед причин такої пасивності населення експерти називають зневіру та розчарованість людей, низький рівень довіри, в першу чергу до інститутів влади, брак інформації, бідність, незнання інструментів впливу на стан справ у громаді та відсутність відповідної інфраструктури [2].

На думку членів ВГО «Асоціація сприяння самоорганізації населення», небайдужим та активним мешканцям, представникам ОСН не вистачає професіоналізму, що проявляється у відсутності знань про можливості, які дають нам інструменти місцевої демократії, знань у сфері законодавства, прав людини, державного устрою, знань щодо повноважень органів, установ та організацій, які можуть вирішувати їх питання. Бракує обізнаності щодо доступу до публічної інформації, фінансової грамотності, знань про інструменти контролю влади, знань про можливості, які дають нам інструменти місцевої демократії, системності у роботі, знань про успішні приклади, комунікативних навичок та можливостей мережуватися, вміння зрозуміло ставити питання і надавати пропозиції по вирішенню проблем замість радикалізму та протестів, вміння залучати фінансові ресурси.

Тож серед сучасних тенденцій розвитку ОСН слід виокремити напрям $з$ організації та роз'яснення їх роботи поміж жителів відповідної території [11, с. 25]. Різко постає проблема отримання належної інформації про їх сутність та діяльність, а також щодо практики реалізації повноважень ОСН, повідомлення про їх значення у вирішенні соціально-економічних, культурних, побутових 
та інших потреб тощо. Навіть в умовах недосконалості діючого законодавства, відповідно до думки науковців [10, с. 108], необхідно на місцях створювати та знаходити оптимальні правові засади щодо ефективної взаємодії між ОСН та ОМС. Подолання зазначених проблем можливе шляхом проведення локальної нормотворчості, тобто шляхом прийняття локальних нормативно-правових актів, в тому числі статутів ТГ. Вказуючи на величезну роль, яку повинні відігравати статути ТГ у житті відповідних населених пунктів, науковці зазначають, що, незважаючи на наявність певних законодавчих приписів щодо регламентації нормативно-правового статусу ОСН, саме у цих «локальних конституціях» і повинні бути відображені специфічні, індивідуальні риси місцевої політики з цього питання $[12$, с. 15$]$.

Лише за умови об'єднання зусиль активних жителів міської громади та органів МСВ можливий сталий розвиток міста, підвищення соціально-економічного рівня життя населення.

Висновки. Аналіз сучасного стану проблем та перспектив розвитку ОСН в містах України, зокрема в місті Миколаєві, їх ролі в системі МСВ в умовах децентралізації державної влади дозволяє виокремити, як позитивні так і негативні аспекти їх діяльності.

До позитивних треба віднести те, що ОСН там де вони дійсно працюють $є$ достатньо ефективним інструментом вирішення населенням громади питань місцевого значення, тому що будучи наближені до жителів певної території (вулиці, кварталу, мікрорайону), активізують його ініціативність навколо проблеми, яку треба вирішити. Також ОСН сприяють розвитку демократії на місцевому рівні, тому що справжня демократія й починається з особистої участі населення у вирішенні питань, які стосуються їхнього життя.

До негативних тенденцій розвитку ОСН треба віднести: складну процедуру створення ОСН; відсутність налагодженої системи взаємодії між ТГ й органами МСB; незацікавленість органів МСВ в $\mathrm{OCH}$, а тому небажання враховувати пропозиції громадян й залучати їх до розв'язання місцевих проблем; недостатня фінансова підтримка, заохочення та стимулювання ОСН з боку органів МСB; патерналістські очікування населення, сподівання, що влада повинна 
вирішувати всі їх проблеми; низка активність громадян, як реальної впливової сили у вирішенні проблем території громади, люди не вірять, що зможуть щось реально змінити в місті, селі, селищі.

Також для подолання існуючої ситуації, що склалась у Миколаєві та активізації формування й розвитку ОСН вважаємо за необхідне:

1) розробити та затвердити Програму розвитку ОСН міста на 2019-2024 рр.;

2) депутатському корпусу й посадовим особам місцевого самоврядування проводити роз яснювальну, агітаційну роботу серед жителів міста щодо переваг створення ОСН;

3) міської раді забезпечити фінансову підтримку їх діяльності;

4) міськвиконкому з Інститутом державного управління ЧНУ ім. П. Могили проводити навчання, семінари, круглі столи, підвищення кваліфікації членів існуючих ОСН;

5) залучати ОСН до програм бюджету участі, надаючи їм перевагу в отриманні грантів;

6) використовувати потенціал ОСББ, мотивувати їх об єднуватись, створювати ОСН у формі вуличних, квартальних комітетів, комітетів мікрорайону задля вирішення проблем мікрорегіонального рівня;

7) забезпечити обов'язковість участі керівників (представників) ОСН у засіданнях Громадської Ради при міськвиконкомі, при вирішенні питання благоустрою територій міста, питання виділення земельних ділянок під забудову, адже все частіше жителі мікрорайонів вимушені вдаватися до протестних дій, щоб зупинити незаконні будівництва, які порушують Державні будівельні норми, знищують пам'ятки історико-культурної спадщини та об'єкти природно-заповідного фонду, руйнують зони рекреаційного та оздоровчого призначення, порушують принцип цільового використання земель загального користування, громадської та жилої забудови.

Тільки за умови коли міська влада дасть зрозуміти жителям міста, що вони є справжніми творцями свого добробуту, шляхом підтримки інституцій самоорганізації, можна буде говорити про розвиток громадянського суспільства в Україні та зростання рівня життя громадян. 
Підкреслімо, що саме органи самоорганізації населення в умовах децентралізації державної влади й реформування місцевого самоврядування можуть стати допоміжним ресурсом місцевої владі у вирішенні проблем соціального, економічного та культурного життя громадян на рівні територіальної громади, сприяти їх самоорганізації, розвитку ініціативи й відповідальності. Стати ефективним інструментом реалізації місцевих питань та розвитку країни, як демократичної держави.

\section{Стаття надійшла до редакціi: 17.01.2019}

\section{BODIES OF SELF-ORGANIZATION OF THE POPULATION IN UKRAINE: CONTEMPORARY STATE, PROBLEMS AND DEVELOPMENT PERSPECTIVES}

Alexander Evtushenko, Doctor of Political sciences, professor Black Sea National University of Petro Mohyla, Mykolaiv, Ukraine

Lesya Stadnichenko, magistrate at the Institute of Public Administration, Petro Mohyla Black Sea National University, Mykolaiv, Ukraine

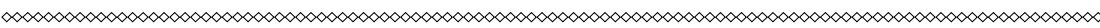

The article deals with the current problems and prospects of selforganization bodies and their development in the cities of Ukraine, in particular in the city of Mykolayiv, and their role in the system of local self-government in terms of decentralization of state power. It is defined both positive and negative aspects of their work.

Among the positive ones we can determine the fact that the bodies of self-organization of the population are rather effective tools for solving problems of local importance, because they are close to residents of a certain territory (street, district. Bodies of self-organization of the population activate the population around the unresolved local problems and promote the development of democracy at the local level, because true democracy begins with personal participation of the population where they solve issues related to their lives. 
The negative tendencies of bodies development of self-organization of the population are the following: a complex procedure for their creation; absence of a well-established system of interaction between the territorial community and local self-governmental bodies; the lack of interest of local self-government bodies in the bodies of self-organization of the population, and therefore the reluctance to take into account the proposals of citizens and involve them in solving local problems; insufficient financial support, encouragement and promotion of bodies of self-organization of the population by local self-government bodies; paternalistic expectations of the population, the hope that the government should solve all their problems; a number of active citizens, as a real influential force in solving the problems of the community, people do not believe that they will be able to really change something in the city, village, etc.

It is determined that the bodies of self-organization of the population in terms of decentralization and reformation of local self-government can become an auxiliary resource of local authorities in solving problems of social, economic and cultural life of citizens at the level of the territorial community, to promote their self-organization, development of initiative and responsibility. However, the understanding that the bodies of selforganization of the population are an effective instrument for realizing local issues and developing the country as a democratic state only encourages a small number of territorial communities to actively develop and support the work of the bodies of self-organization of the population.

Keywords: bodies of self-organization of the population, local selfgovernment, bodies of local self-government, state power, democracy, decentralization, territorial community.

\section{Received: 17.01.2019}




\section{References}

1. Hlazova, Ya. V., \& Maksyshko, N. K. (2015). Doslidzhennia dynamiky protsesiv samoorhanizatsii naselennia $\mathrm{v}$ terytorialnykh hromadakh rehioniv Ukrainy. [Research of dynamics of processes of self-organization of population in territorial communities of regions of Ukraine] Elektronnyi zhurnal «Efektyvna ekonomika», 12. Retrieved from http://www.economy.nayka.com. ua/pdf/12_2015/22.pdf [in Ukrainian].

2. Detsentralizatsiia bez demokratyzatsii abo chomu mistseva demokratiia maie znachennia? (Pryklad Ukrainy) [Decentralization without democratization or why does local democracy matter? (Example of Ukraine)].Analitychna zapyska VHO «Asotsiatsiia spryiannia samoorhanizatsii naselennia». Analitychnyi daizhest, 9, 2018. Retrieved from http://samoorg.com.ua/pomoshh-aktivistam/ analityka/ [in Ukrainian].

3. Ekspert: Paternalizm zalyshaietsia providnoiu tsinnisnoiu ustanovkoiu ukraintsiv. [Expert: Paternalism remains the leading value-setting of Ukrainians]. Retrieved from https: //dt.ua/article/print/ARCHIVE/ekspert_paternalizm zalishaetsya_providnoyu_tsinnisnoyu_ustanovkoyu_ukrayintsiv.html [in Ukrainian]

4. Eksperty nazvaly naibilsh komfortne misto dlia prozhyvannia $\mathrm{v}$ Ukraini. [Experts named the most comfortable city for living in Ukraine.]. RBK-Ukraina. Retrieved from https://styler.rbc.ua/ukr/zhizn/eksperty-nazvalisamyy-komfortnyy-gorod-prozhivaniya-1529783465.html [in Ukrainian]

5. Ieremenko M. (2011). Orhany samoorhanizatsii naselennia yak suchasna forma spilnotnoho zghurtuvannia ukrainskykh hromadian. [Bodies of self-organization of the population as a modern form of community unification of Ukrainian citizens] Visnyk Kyivskoho natsionalnoho universytetu imeni Tarasa Shevchenka. 15, 47- 51 [in Ukrainian]

6. Za desiat rokiv asotsiatsiia orhaniv samoorhanizatsii naselennia stala tsentrom vzaiemodii meshkantsiv ta orhaniv vlady. [For ten years, the Association of Self-Organization Bodies has become the center of interaction between residents and authorities]. Retrieved from http://www.vmr.gov.ua/ Lists/CityNews/ShowNews.aspx?ID=3838 [in Ukrainian]

7. Zvit pro diialnist upravlinnia $\mathrm{z}$ pytan vzaiemodii $\mathrm{z}$ orhanamy samoorhanizatsii naselennia Odeskoi miskoi rady za 2017 rik. [Report on the activities of the management on issues of interaction with the bodies of selforganization of the population of the Odessa City Council for 2017]. Retrieved from http://omr.gov.ua/ru/departments/74906 [in Ukrainian] 
8. Zubko H. HROMADna reforma: shcho dala detsentralizatsiia. [CURRENT reform: what has been decentralized]. Ekonomichna pravda. Retrieved from https://www.epravda.com.ua/columns/2017/08/4/627740/ [in Ukrainian].

9. Konstytutsiia Ukrainy (zi zminamy). [The Constitution of Ukraine]. Vidomosti Verkhovnoi Rady Ukrainy. 1996. 30, 141 [in Ukrainian].

10. Lytvyna O. P., Kampo V. M., Korniienko M. I. (2006). Mistseve samovriaduvannia ta samoorhanizatsiia naselennia $\mathrm{v} \mathrm{m}$. Kyievi stan, problemy ta ryzyky rozvytku [Local self-government and self-organization of the population in Kiev: the state, problems and risks of development]. Materialy Vseukr. nauk./ prakt. konf. (Kyiv, 15 berez. 2006 r.), 217. [in Ukrainian].

11. Mukshymenko A. P., Rudyk S. Ya., Yakovets I. S. (2006). Orhany samoorhanizatsii naselennia. Suchasni tendentsii. Osnovy stvorennia, problemy funktsionuvannia ta rozvytku. [Bodies of self-organization of the population. Contemporary trends. Foundations, problems of functioning and development] nauk./metod. posib, Kyiv, 207 [in Ukrainian]

12. Orlovskyi O. S. (2004). Pravovyi status orhaniv samoorhanizatsii naselennia [Legal status of bodies of self-organization of the population]. Extended abstract of candidate's thesis. Odessa: SumSU. Retrieved from: http:// dspace.onua.edu.ua/bitstream/handle/11300/1364/.pdf [in Ukrainian]

13. Postmaidanni praktyky samoorhanizatsii hromadian Ukrainy $u$ vyrishenni pytan mistsevoho znachennia [Postmayday practice of selforganization of citizens of Ukraine in solving local issues]. Analitychna zapyska Natsionalnoho instytutu stratehichnykh doslidzhen. Retrieved from http:// www.niss.gov.ua/content/articles/files/1_Pelivanova-06.2018-ddb84.pdf [in Ukrainian]

14. Pro blahoustrii naselenykh punktiv Zakon Ukrainy vid 06.09.2005 roku. 2807-IV [About the improvement of settlements The Law of Ukraine 06.09, 2807-IV]. Vidomosti Verkhovnoi Rady Ukrainy. 2005. 49, 517. Retrieved from https://zakon.rada.gov.ua/laws/show/2807-15 [in Ukrainian]

15. Pro hromadskyi kontrol u sferi blahoustroiu m. Kyieva. Rozporiadzhennia Kyivskoi miskoi derzhavnoi administratsii 12.12.2008. 1730 (Iz zminamy, [About public control in the area of improvement of Kiev 12.12.2008. 1730]. Vnesenymy zghidno z Rozporiadzhenniam KMDA, 1015 vid 21.06.2011) Retrieved from: http://consultant.parus.ua/?doc=08G3SCE193 [in Ukrainian].

16. Pro zatverdzhennia Prohramy rozvytku orhaniv samoorhanizatsii naselennia v misti Mykolaievi na 2012-2013 roky [About approval of the 
Program of development of bodies of self-organization of population in the city of Nikolaev for 2012-2013]. Rishennia Mykolaivskoi miskoi rady, 12/7 vid 23.12.2011. Retrieved from: http://mkrada.gov.ua/documents/3077.html [in Ukrainian].

17. Pro zatverdzhennia Prohramy spryiannia rozvytku hromadianskoho suspilstva u m. Mykolaievi na 2014-2015: [On Approval of the Program for the Promotion of Civil Society Development in Mykolaiv, 2014-2015].Rishennia Mykolaivskoi miskoi rady, 33/6 vid 17.10.2013. Retrieved from https://mkrada. gov.ua/documents/22466.html [in Ukrainian].

18. Pro mistseve samovriaduvannia v Ukraini. Zakon Ukrainy vid 21.05.1997. 280/97 - VR [About local government in Ukraine 21.05.1997. 280/97 - VR]. Vidomosti Verkhovnoi Rady Ukrainy. 1997. 24, 170. Retrieved from: http://zakon3.rada.gov.ua/laws/show/280/97-vr [in Ukrainian].

19. Pro orhany samoorhanizatsii naselennia. Zakon Ukrainy vid 11 lypnia $2001 \mathrm{r}$. [On the bodies of self-organization of the population, July 11, 2001]. Vidomosti Verkhovnoi Rady Ukrainy, 2001, 48, 254 (Iz zminamy, vnesenymy zghidno iz Zakonamy 5492-VI, 20.11.2012, VVR 2013, 51, 716, 2581-VIII 02.10.2018) [in Ukrainian].

20. Pro rehuliuvannia mistobudivnoi diialnosti: Zakon Ukrainy vid 17liutoho 2011 roku 3038-VI [On the regulation of urban development activities from 17th of July 2011, 038-VI]. Retrieved from: https://zakon.rada. gov.ua/laws/show/3038-17 [in Ukrainian].

21. Pro spryiannia rozvytku hromadianskoho suspilstva v Ukraini Ukaz Prezydenta Ukrainy vid 26 liutoho 2016 roku, 68/2016 [Promoting the development of civil society in Ukraine Decree of the President of Ukraine, February 26, 2016, 68/2016]. Retrieved from: http://zakon4.rada.gov.ua/laws/ show/68/2016 [in Ukrainian].

22. Pro khid vykonannia u 2017 rotsi miskoi tsilovoi Prohramy rozvytku orhaniv samoorhanizatsii naselennia v m. Odesi na 2016-2019 roky, [About the progress in 2017 of the city target program for the development of bodies of self-organization of the population in Odessa in 2016-2019]. Zatverdzheno rishenniam Odeskoi miskoi rady vid 16 hrudnia 2015 roku, 22-VII: Rishennia vykonavchoho komitetu Odeskoi miskoi rady 172 vid 26.04.2018. Retrieved from: http://omr.gov.ua/ru/acts/committee/106385/ [in Ukrainian].

23. Sydoryna T. Yu.(2005). Dva veka sotsyalnoi polytyky [Two centuries of social policy] / Moskva : RHHU, 442 [in Russian]. 


\section{Відомості про авторів / Information about the Authors}

Євтушенко Олександр Никифорович: Чорноморський національний університет імені Петра Могили: вул. 68 десантників 10, м. Миколаїв, 54003, Україна.

Alexander Evtushenko: Institute of Public Administration Black Sea National University of Petro Mohyla: 68 Desantnykiv str. 10, Mykolaiv, 54003, Ukraine.

\section{ORCID.ORG./ 0000-0002-5161-3312}

\section{E-mail: alnievt@ukr.net}

Стадніченко Леся Михайлівна: Державна служба з лікарських засобів та контролю за наркотиками у Миколаївській області, вул. Погранична 22/1А, м. Миколаїв, 54207, Україна.

Lesya Stadnichenko: State service of Ukraine on medicines and drugs control, Pogranichnaya str. 22/1A, Mykolaiv, 54207, Ukraine.

\section{E-mail: alnievt@ukr.net}

